\title{
Synthesis, Crystal Structure and Characterization of $\mathrm{Cu}(\mathrm{II})$ and $\mathrm{Cd}(\mathrm{II})$ Coordination Compounds Based on Ligand 2-(3-(Pyridin-2-yl)-1H-pyrazol-1-yl)acetic Acid
}

\author{
Ya-Jun Zhang, Cui-Juan Wang, Kai-Li Mao, Xiao-Lei Liu, Shuai Huang, Yan Tong, and Xian-Li Zhou \\ Department of Chemistry and Chemical Engineering, School of Life Science and Bioengineering, Southwest Jiaotong University, \\ Chengdu, Sichuan 610031, People's Republic of China. ${ }^{*}$ E-mail: wangcuijuan@home.swjtu.edu.cn \\ Received January 2, 2014, Accepted March 18, 2014
}

\begin{abstract}
Two novel coordination compounds $\left[\mathrm{Cu}_{2}(\text { pypya })_{3}\left(\mathrm{H}_{2} \mathrm{O}\right)_{2}\right] \cdot \mathrm{Cl} \cdot\left(\mathrm{H}_{2} \mathrm{O}\right)_{5}(\mathbf{1})$ and $\left\{\left[\mathrm{Cd}(\text { pypya })(\text { ta })_{1 / 2}\right] \cdot \mathrm{H}_{2} \mathrm{O}\right\}_{\mathrm{n}}(\mathbf{2})$ (Hpypya=2-(3-(pyridin-2-yl)-1H-pyrazol-1-yl)acetic acid, $\mathrm{H}_{2}$ ta $=$ terephthalic acid) were synthesized and characterized by single X-ray diffraction. Structure determination reveals that complex $\mathbf{1}$ and complex 2 crystallize in the triclinic system, with the $P-1$ space group. The asymmetric unit of $\mathbf{1}$ contains two $\mathrm{Cu}(\mathrm{II})$ ions, and their coordination modes are different. These units of complex $\mathbf{1}$ are linked together via hydrogen bonds and $\pi-\pi$ interactions, and the 3D structure of complex 1 was formed. Complex 2, a mononuclear $\mathrm{Cd}$ (II) coordination compound, has a 2D structure which was constructed via coordination bonds. TGA and fluorescence spectra analysis of complex $\mathbf{1}$ and complex $\mathbf{2}$ have also been studied. In addition, the geometry parameters of complex 1 have been optimized with the B3LYP method of density functional theory (DFT) to explain its coordination behavior. The electronic properties of the complex $\mathbf{1}$ and ligand Hpypya have been investigated based on the nature bond orbital (NBO) analysis at the B3LYP level of theory. The result verifies that the synergistic effect have occurred in the compound.
\end{abstract}

Key Words : Coordination compound, TGA, Fluorescence spectra, DFT calculations

\section{Introduction}

In recent years, much attention has been paid to the design and construction of metal-organic coordination complexes. ${ }^{1-6}$ One reason is that the structure of these complexes is novel. The other reason is that these complexes have many potential applications in, for example, magnetism, gas separation, optoelectronics and biomimetic materials. ${ }^{7-11}$ Studies in this field have been focused on the design and preparations of coordination complexes, as well as structure-property relationships. Among the reported organic ligands, carboxylate compounds and $N$-donor compounds are the most efficient families and play dominant roles in fabrication of coordination complexes. Hpypya and $\mathrm{H}_{2} \mathrm{ta}$ (Scheme 1) are examples of these organic ligands. Moreover, in ligand Hpypya, the $-\mathrm{CH}_{2}$ - spacer between the pyrazole ring and carboxylate group offers flexible orientations of the carboxylate arm, favoring the formation of varied framework structures. In conclusion, Hpypya and $\mathrm{H}_{2}$ ta are excellent and versatile building blocks. Several studies of coordination frameworks coordinated by Hpypya or $\mathrm{H}_{2}$ ta have been reported. ${ }^{12-14}$

In this study, coordination sites come from $\mathrm{N}$ atoms and $\mathrm{O}$ atoms which are provided by ligand pypya anions, ta anions and water molecules. Weak interactions, such as hydrogen bonds ${ }^{15}$ and $\pi-\pi$ interactions, ${ }^{16}$ play important

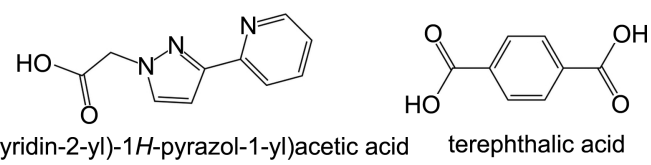

2-(3-(pyridin-2-yl)-1H-pyrazol-1-yl)acetic acid terephthalic acid

Scheme 1. Chemical structure of ligands Hpypya and $\mathrm{H}_{2}$ ta. roles in the formation of complexes; they can link discrete subunits or low-dimensional entities into high-dimensional supramolecular networks. ${ }^{17,18}$ Herein, we report the synthesis, $\mathrm{X}$-ray single crystal structure of coordination complexes $\left[\mathrm{Cu}_{2}(\text { pypya })_{3}\left(\mathrm{H}_{2} \mathrm{O}\right)_{2}\right] \cdot \mathrm{Cl} \cdot\left(\mathrm{H}_{2} \mathrm{O}\right)_{5}$ and $\left\{\left[\mathrm{Cd}(\text { pypya })(\text { ta })_{1 / 2}\right] \cdot \mathrm{H}_{2} \mathrm{O}\right\}_{\mathrm{n}}$, together with DFT studies to explain coordination behavior of complex 1.

\section{Experimental}

Materials and Physical Measurements. All reagents and solvents employed were commercially available and used as it was received without further purification. Elemental analyses were determined with a Perkin-Elmer model 240C instrument. Thermo gravimetric analyses (TGA) were performed under a NETZSCHSTA 449C thermal analysis instrument from room temperature to $800{ }^{\circ} \mathrm{C}$ under a $\mathrm{N}_{2}$ atmosphere (flow rate $10 \mathrm{~mL} \cdot \mathrm{min}^{-1}$ ) at a heating rate of 10 ${ }^{\circ} \mathrm{C} \cdot \mathrm{min}^{-1}$. Fluorescence spectra were determined on a Varian CARY Eclipse spectrophotometer.

Synthesis of $\left[\mathrm{Cu}_{2}(\text { pypya })_{3}\left(\mathrm{H}_{2} \mathrm{O}\right)_{2}\right] \cdot \mathbf{C l} \cdot\left(\mathrm{H}_{2} \mathrm{O}\right)_{5}(\mathbf{1})$. Hpypya $(30.5 \mathrm{mg}, 0.15 \mathrm{mmol}), \mathrm{NaOH}(6.0 \mathrm{mg}, 0.15 \mathrm{mmol})$ and $\mathrm{NaCl}(3.0 \mathrm{mg}, 0.05 \mathrm{mmol})$ were dissolved in water $(10 \mathrm{~mL})$. $\mathrm{Cu}\left(\mathrm{NO}_{3}\right)_{2} \cdot 3 \mathrm{H}_{2} \mathrm{O}(24 \mathrm{mg}, 0.1 \mathrm{mmol})$ was dissolved in ethanol $(10 \mathrm{~mL})$. The two solutions above were mixed and stirred for $30 \mathrm{~min}$. The resulting mixture was kept at room temperature and X-ray-quality blue rectangular crystals of complex 1 were obtained after about three weeks. (Yield: $41.6 \%$ based on Hpypya). Elemental analysis (\%) for $\mathrm{C}_{30} \mathrm{H}_{38} \mathrm{ClCu}_{2} \mathrm{~N}_{9} \mathrm{O}_{13}$, Found (calcd): C, 40.39 (40.25); H, 4.51 (4.25); N, 14.58 (14.09). 
Synthesis of $\left\{\left[\mathbf{C d}(\text { pypya) (ta) })_{1 / 2}\right] \cdot \mathrm{H}_{2} \mathrm{O}\right\}_{\mathrm{n}}(2)$. A mixture of $\mathrm{Cd}\left(\mathrm{CH}_{3} \mathrm{COO}\right)_{2} \cdot 2 \mathrm{H}_{2} \mathrm{O}(26.7 \mathrm{mg}, 0.1 \mathrm{mmol})$, Hpypya (20.3 $\mathrm{mg}, 0.1 \mathrm{mmol}), \mathrm{H}_{2} \mathrm{ta}(7.3 \mathrm{mg}, 0.05 \mathrm{mmol}), \mathrm{NaOH}(8.0 \mathrm{mg}$, $0.2 \mathrm{mmol})$ and $\mathrm{H}_{2} \mathrm{O}(10 \mathrm{~mL})$ was placed in a $15 \mathrm{ml}$ Teflonlined stainless steel vessel and was heated to $130^{\circ} \mathrm{C}$ for $72 \mathrm{~h}$. Upon cooling to room temperature at a rate of $5^{\circ} \mathrm{C} / \mathrm{h}, \mathrm{X}$-rayquality colorless crystals of complex 2 were obtained. (Yield 34\% based on Hpypya). Elemental analysis (\%) for $\mathrm{C}_{14} \mathrm{H}_{12} \mathrm{CdN}_{3} \mathrm{O}_{5}$, Found (calcd): C, 40.93 (40.52); H, 2.94 (2.89); N, 10.25 (10.13).

Crystal Structure Determination. Single-crystal X-ray diffractions of complex $\mathbf{1}$ and complex $\mathbf{2}$ were performed on a BRUKER SMART 1000 CCD diffractometer equipped with a graphite crystal monochromator situated in the incident beam for data collection. Crystallographic data was collected with Mo-K $\alpha$ radiation $(\lambda=0.71073 \AA)$ at 293(2) $K$. The structure was solved by direct method and refined with the full-matrix least-squares technique using the SHELXS- $97^{19}$ and SHELXL- $97^{20}$ programs. All non-hydrogen atoms were refined with anisotropic thermal parameters. Hydrogen atoms attached to $\mathrm{C}$ atoms were located at geometrically calculated positions to their carrier atoms and refined with isotropic thermal parameters included in the final stage of the refinement. A summary of the detailed crystallographic data and structure refinement is given in Table 1, and selected bond lengths and angles of complex 1 and complex 2 are listed in Table 2 and Table 3 respectively.

Computation Details. The calculations were carried out using Gaussian03 program suite, ${ }^{21}$ including optimized geometries and calculation of vibrational frequencies were carried out at the B3LYP ${ }^{22,23}$ level of theory. Mulliken population analysis was also performed under this method. We employed 6-31G(d) basis set for $\mathrm{H}, \mathrm{C}, \mathrm{N}$ and $\mathrm{O}$, and the LANL2DZ effective core potential (EPC) set of Hay and $\mathrm{Wadt}^{24}$ for $\mathrm{Cu}$. Geometry optimization was performed for complex 1, and the attainment of energy minimum was verified by calculating the vibrational frequencies that result

Table 2. Selected bond lengths $(\AA)$ and bond angles $\left(^{\circ}\right)$ of $\mathbf{1}$

\begin{tabular}{lll}
\hline & Experimental & Optimized \\
\hline $\mathrm{Cu}(1)-\mathrm{O}(3)$ & $1.951(6)$ & $1.981(3)$ \\
$\mathrm{Cu}(1)-\mathrm{O}(7)$ & $1.968(6)$ & $2.006(0)$ \\
$\mathrm{Cu}(1)-\mathrm{N}(2)$ & $2.020(7)$ & $2.029(9)$ \\
$\mathrm{Cu}(1)-\mathrm{N}(1)$ & $2.026(7)$ & $2.034(5)$ \\
$\mathrm{Cu}(2)-\mathrm{O}(2)$ & $1.971(6)$ & $1.985(7)$ \\
$\mathrm{Cu}(2)-\mathrm{N}(5)$ & $1.995(7)$ & $2.023(1)$ \\
$\mathrm{Cu}(2)-\mathrm{N}(18)$ & $2.002(7)$ & $2.031(4)$ \\
$\mathrm{Cu}(2)-\mathrm{N}(4)$ & $2.048(8)$ & $2.163(0)$ \\
$\mathrm{Cu}(2)-\mathrm{N}(7)$ & $2.236(7)$ & $2.237(3)$ \\
$\mathrm{O}(3)-\mathrm{Cu}(1)-\mathrm{O}(7)$ & $91.1(2)$ & $89.5(2)$ \\
$\mathrm{O}(3)-\mathrm{Cu}(1)-\mathrm{N}(2)$ & $96.2(3)$ & $96.8(6)$ \\
$\mathrm{O}(7)-\mathrm{Cu}(1)-\mathrm{N}(1)$ & $91.3(3)$ & $93.5(2)$ \\
$\mathrm{N}(2)-\mathrm{Cu}(1)-\mathrm{N}(1)$ & $80.3(3)$ & $80.3(3)$ \\
$\mathrm{O}(2)-\mathrm{Cu}(2)-\mathrm{N}(18)$ & $89.2(3)$ & $91.2(9)$ \\
$\mathrm{N}(5)-\mathrm{Cu}(2)-\mathrm{N}(18)$ & $173.2(3)$ & $172.0(3)$ \\
$\mathrm{N}(5)-\mathrm{Cu}(2)-\mathrm{N}(4)$ & $79.6(3)$ & $78.3(3)$ \\
$\mathrm{N}(18)-\mathrm{Cu}(2)-\mathrm{N}(4)$ & $93.5(3)$ & $94.9(5)$ \\
$\mathrm{N}(18)-\mathrm{Cu}(2)-\mathrm{N}(7)$ & $78.7(3)$ & $78.4(5)$ \\
\hline
\end{tabular}

Table 1. Crystal data and structure refinement for $\mathbf{1}$ and $\mathbf{2}$

\begin{tabular}{lll}
\hline & $\mathbf{1}$ & $\mathbf{2}$ \\
\hline Empirical formula & $\mathrm{C}_{30} \mathrm{H}_{38} \mathrm{ClCu}_{2} \mathrm{~N}_{9} \mathrm{O}_{13}$ & $\mathrm{C}_{14} \mathrm{H}_{12} \mathrm{CdN}_{3} \mathrm{O}_{5}$ \\
Formula weight & 895.22 & 414.67 \\
Temperature & $293(2) \mathrm{K}$ & $293(2) \mathrm{K}$ \\
Wavelength & $0.71073 \AA$ & $0.71073 \AA$ \\
Crystal system & Triclinic & Triclinic \\
Space group & $P-1$ & $P-1$ \\
$\mathrm{a}(\AA), \alpha\left(^{\circ}\right)$ & $11.1068(8), 78.953(6)$ & $4.7823(8), 78.319(2)$ \\
$\mathrm{b}(\AA), \beta\left({ }^{\circ}\right)$ & $11,9974(9), 84.648(6)$ & $10.8136(2), 82.939(2)$ \\
$\mathrm{C}(\AA), \gamma\left({ }^{\circ}\right)$ & $15.9469(1), 73.592(6)$ & $14.3253(0), 89.346(1)$ \\
Volume $\left(\AA^{3}\right)$ & $1998.9(3)$ & $719.9(2)$ \\
$Z$, Calculated density $\left(\mathrm{Mg} / \mathrm{m}^{3}\right)$ & $2,1.487$ & $2,1.913$ \\
$\left.\mu(\mathrm{mm})^{-1}\right)$ & 1.201 & 1.547 \\
Crystal size $\left.(\mathrm{mm})^{3}\right)$ & $0.04 \times 0.03 \times 0.02$ & $0.03 \times 0.02 \times 0.02$ \\
$F(000)$ & 920 & 410 \\
$\theta$ range for data collection & 2.60 to $25.02^{\circ}$ & 2.64 to 25.02 \\
Reflections collected & 13256 & 4389 \\
Independent reflections & $7038\left[R_{\text {int }}=0.0650\right]$ & $2536\left[R_{\text {int }}=0.0738\right]$ \\
Data/restraints/parameters & $7038 / 0 / 496$ & $2536 / 498 / 208$ \\
Goodness-of-fit on $F^{2}$ & 1.066 & 1.038 \\
Final $R$ indices $[I>2 \sigma(I)]$ & $R_{1}=0.0841, w R_{2}=0.2276$ & $R_{1}=0.0660, w R_{2}=0.1283$ \\
$R$ indices $($ all data $)$ & $R_{1}=0.1409, w R_{2}=0.2843$ & $R_{1}=0.1012, w R_{2}=0.1602$ \\
Largest diff. peak and hole & 1.694 and -0.896 e. $\AA^{-3}$ & 1.297 and $-1.403 \mathrm{e} . \AA^{-3}$ \\
\hline
\end{tabular}

${ }^{a} R I=\Sigma\left(|| \mathrm{F}_{\mathrm{o}}|-| \mathrm{F}_{\mathrm{c}}||\right) / \Sigma\left|\mathrm{F}_{\mathrm{o}}\right|{ }^{b} \mathrm{wR}_{2}=\left[\Sigma\left(\mathrm{w}\left(\mathrm{F}_{\mathrm{o}}{ }^{2}-\mathrm{F}_{\mathrm{c}}{ }^{2}\right)^{2}\right) / \Sigma\left(\mathrm{w} \mid \mathrm{F}_{\mathrm{o}}{ }^{2}{ }^{2}\right)\right]^{1 / 2}$ 
Table 3. Selected bond lengths $(\AA)$ and bond angles $\left(^{\circ}\right)$ of $\mathbf{2}$

\begin{tabular}{llll}
\hline $\mathrm{Cd}(1)-\mathrm{O}(1) \# 1$ & $2.228(6)$ & $\mathrm{O}(4)-\mathrm{Cd}(1)-\mathrm{N}(1)$ & $84.0(3)$ \\
$\mathrm{Cd}(1)-\mathrm{O}(2) \# 2$ & $2.261(6)$ & $\mathrm{O}(1) \# 1-\mathrm{Cd}(1)-\mathrm{N}(2)$ & $99.6(2)$ \\
$\mathrm{Cd}(1)-\mathrm{O}(4)$ & $2.298(7)$ & $\mathrm{O}(4)-\mathrm{Cd}(1)-\mathrm{N}(2)$ & $129.8(3)$ \\
$\mathrm{Cd}(1)-\mathrm{N}(1)$ & $2.319(8)$ & $\mathrm{N}(1)-\mathrm{Cd}(1)-\mathrm{N}(2)$ & $69.4(2)$ \\
$\mathrm{Cd}(1)-\mathrm{N}(2)$ & $2.437(7)$ & $\mathrm{O}(1) \# 1-\mathrm{Cd}(1)-\mathrm{O}(3)$ & $77.7(2)$ \\
$\mathrm{Cd}(1)-\mathrm{O}(3)$ & $2.568(7)$ & $\mathrm{O}(2) \# 2-\mathrm{Cd}(1)-\mathrm{O}(3)$ & $90.5(2)$ \\
$\mathrm{O}(1) \# 1-\mathrm{Cd}(1)-\mathrm{O}(2) \# 2$ & $90.4(2)$ & $\mathrm{O}(4)-\mathrm{Cd}(1)-\mathrm{O}(3)$ & $53.0(3)$ \\
$\mathrm{O}(1) \# 1-\mathrm{Cd}(1)-\mathrm{O}(4)$ & $130.6(2)$ & $\mathrm{N}(1)-\mathrm{Cd}(1)-\mathrm{O}(3)$ & $114.6(3)$ \\
$\mathrm{O}(2) \# 2-\mathrm{Cd}(1)-\mathrm{O}(4)$ & $91.6(2)$ & $\mathrm{N}(2)-\mathrm{Cd}(1)-\mathrm{O}(3)$ & $175.9(3)$ \\
$\mathrm{O}(1) \# 1-\mathrm{Cd}(1)-\mathrm{N}(1)$ & $120.0(2)$ & $\mathrm{O}(2) \# 2-\mathrm{Cd}(1)-\mathrm{N}(2)$ & $86.4(2)$ \\
$\mathrm{O}(2) \# 2-\mathrm{Cd}(1)-\mathrm{N}(1)$ & $143.1(2)$ & & \\
\hline
\end{tabular}

Symmetry codes: (\#1) $-x+1,-y+1,-z ;(\# 2)-x+2,-y+1,-z$

in absence of imaginary eigenvalues.

\section{Results and Discussion}

Structure of $\left[\mathrm{Cu}_{2}(\text { pypya })_{3}\left(\mathrm{H}_{2} \mathrm{O}\right)_{2}\right] \cdot \mathbf{C l} \cdot\left(\mathrm{H}_{2} \mathrm{O}\right)_{5}(\mathbf{1})$. Singlecrystal X-ray diffraction analysis reveals that complex $\mathbf{1}$ crystallizes in the triclinic space group $P-1$. The asymmetric unit of $\mathbf{1}$ is composed of two $\mathrm{Cu}$ (II) ions, three pypya anions, one chloride ion and seven water molecules. The two $\mathrm{Cu}$ (II) ions are all five coordinated, and the coordination geometry around $\mathrm{Cu}(\mathrm{II})$ in complex $\mathbf{1}$ is a distorted tetragonal pyramid.

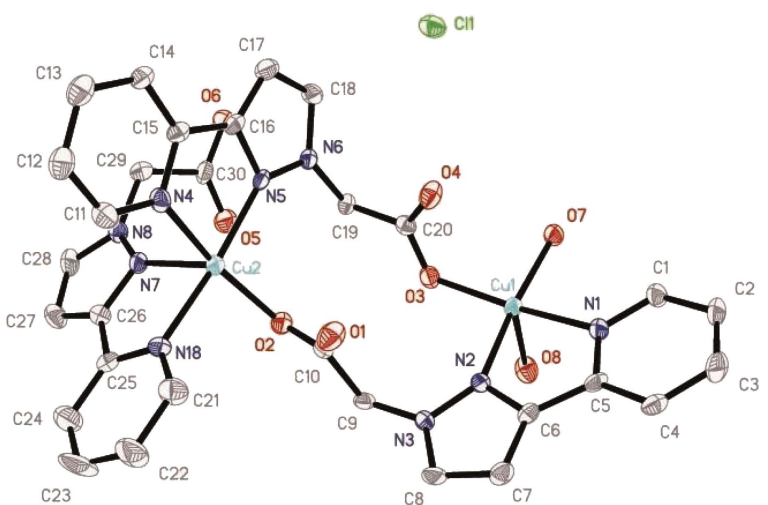

Figure 1. Coordination environment of $\mathrm{Cu}(\mathrm{II})$ atoms in complex 1 with thermal ellipsoids at $30 \%$ probability level.
The $\mathrm{Cu}$ l center is coordinated by two nitrogen atoms from pypya anion, one carboxylic oxygen atom from pypya anion and two oxygen atoms from water molecules. The $\mathrm{Cu} 2$ center is coordinated by four nitrogen atoms from two pypya anions and one carboxylic oxygen atom from pypya anion (Figure 1). The $\mathrm{Cu}-\mathrm{N}$ distances fall in the range 1.996-2.237 $\AA$, while the $\mathrm{Cu}-\mathrm{O}$ distances range from 1.952 to $1.972 \AA$. The $\mathrm{Cu}-\mathrm{N}$ and $\mathrm{Cu}-\mathrm{O}$ distances are quite similar to literature date. ${ }^{25-27}$ It reveals that the coordination ability of $\mathrm{O}$ atoms is stronger than $\mathrm{N}$ atoms in complex 1.

Hydrogen bonds and $\pi-\pi$ interactions are important in forming extended solid state structure. Chloride ion and carboxyl group which is not coordinated to metal ion are bonded to water molecules through hydrogen bonds. The information of hydrogen bonds is shown in Table 4. As shown in Figure 2, the asymmetric units are interlinked via the hydrogen bonding interactions and offset $\pi-\pi$ interactions (between ring N1-C1-C2-C3-C4-C5 and ring N2-N3-C6C7-C8, centroid-to-centroid $3.7708 \AA$ ). Thus, infinite onedimensional (1D) 20-membered ring-shaped chains are formed. As is shown in Figure 3, these chains are further stacked together into $2 \mathrm{D}$ structure via interchain $\pi$ - $\pi$ stacking interactions (between ring N4-C11-C12-C13-C14-C15 and ring N5-N6-C16-C17-C18, centroid-to-centroid 3.9234 Å).

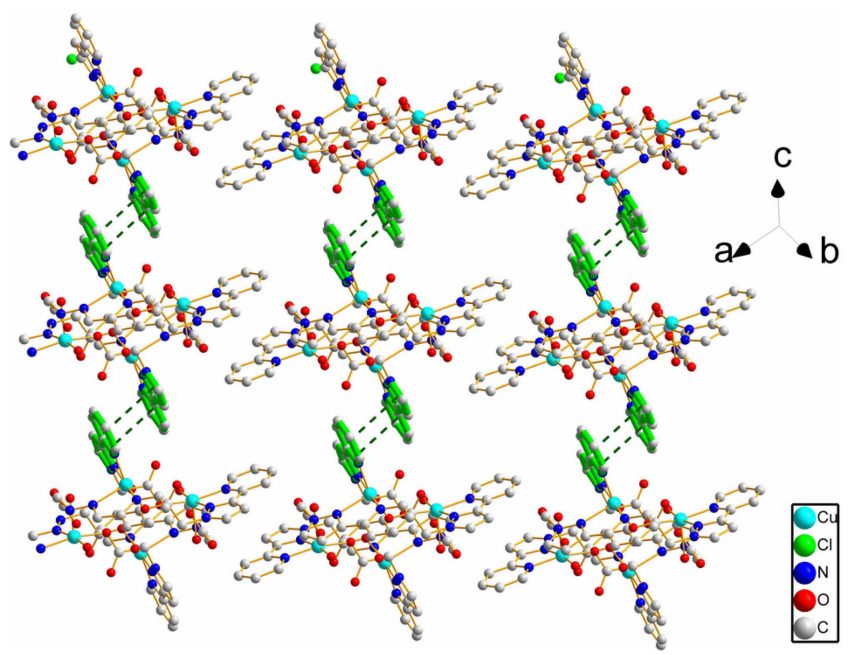

Figure 3. Interchain $\pi-\pi$ stacking interactions of complex 1 .

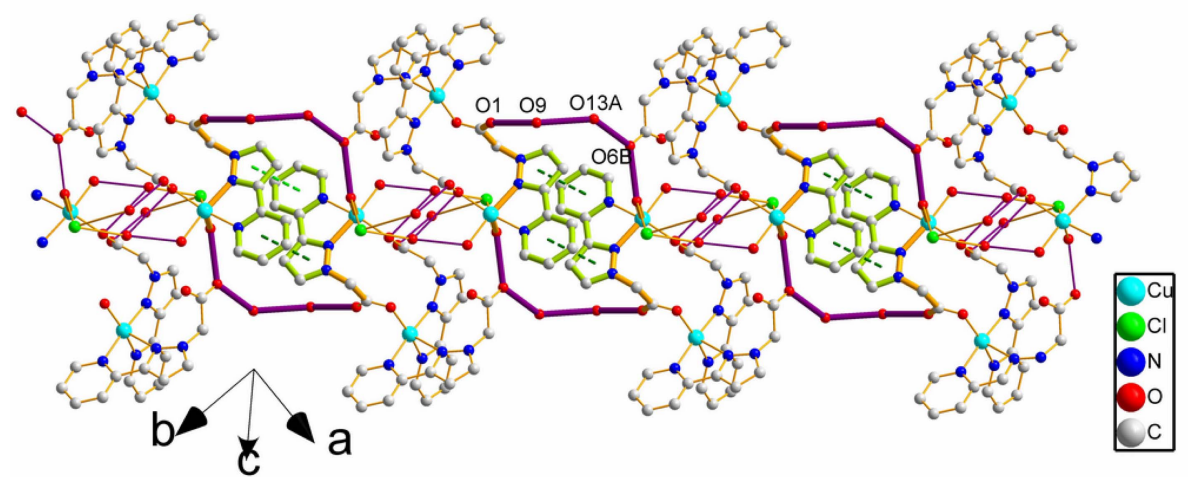

Figure 2. The 1D supramolecular architecture of 1 constructed by hydrogen bonds and $\pi$ - $\pi$ interactions. 
Table 4. Hydrogen bond lengths $(\AA)$ and bond angles $\left({ }^{\circ}\right)$ of $\mathbf{1}$

\begin{tabular}{lllll}
\hline $\mathrm{D}-\mathrm{H} \ldots \mathrm{A}$ & $\mathrm{d}(\mathrm{D}-\mathrm{H})$ & $\mathrm{d}(\mathrm{H} \ldots \mathrm{A})$ & $\mathrm{d}(\mathrm{D} \ldots \mathrm{A})$ & $\angle \mathrm{DHA}$ \\
\hline $\mathrm{O}(7)-\mathrm{H}(7 \mathrm{C}) \ldots \mathrm{O}(5) \# 1$ & 0.85 & 1.95 & 2.6221 & 135 \\
$\mathrm{O}(7)-\mathrm{H}(7 \mathrm{D}) \ldots \mathrm{O}(11)$ & 0.85 & 2.02 & 2.6769 & 134 \\
$\mathrm{O}(8)-\mathrm{H}(8 \mathrm{~B}) \ldots \mathrm{Cl}(1) \# 1$ & 0.85 & 2.60 & 3.2008 & 129 \\
$\mathrm{O}(8)-\mathrm{H}(8 \mathrm{C}) \ldots \mathrm{O}(6) \# 1$ & 0.85 & 1.85 & 2.68 & 167 \\
$\mathrm{O}(9)-\mathrm{H}(9 \mathrm{~F}) \ldots \mathrm{O}(1)$ & 0.85 & 1.96 & 2.7712 & 159 \\
$\mathrm{O}(10)-\mathrm{H}(10 \mathrm{C}) \ldots \mathrm{O}(12) \# 1$ & 0.85 & 2.23 & 2.793 & 123 \\
$\mathrm{O}(11)-\mathrm{H}(11 \mathrm{~B}) \ldots \mathrm{Cl}(1)$ & 0.85 & 2.75 & 3.0978 & 106 \\
$\mathrm{O}(11)-\mathrm{H}(11 \mathrm{C}) \ldots \mathrm{O}(3) \# 1$ & 0.85 & 1.96 & 2.8031 & 173 \\
$\mathrm{O}(12)-\mathrm{H}(12 \mathrm{~A}) \ldots \mathrm{Cl}(1)$ & 0.85 & 2.36 & 3.1811 & 163 \\
$\mathrm{O}(12)-\mathrm{H}(12 \mathrm{C}) \ldots \mathrm{O}(4)$ & 0.85 & 2.16 & 3.0041 & 170 \\
$\mathrm{O}(13)-\mathrm{H}(13 \mathrm{C}) \ldots \mathrm{O}(6) \# 1$ & 0.85 & 1.95 & 2.7811 & 165 \\
$\mathrm{O}(13)-\mathrm{H}(13 \mathrm{D}) \ldots \mathrm{O}(9) \# 2$ & 0.85 & 1.95 & 2.7802 & 165
\end{tabular}

Symmetry codes: (\#1) 1-x, 1-y, 1-z; (\#2) -x, 2-y, 1-z.

At last, these 2D planes are stacked together into 3D structure via interplane $\pi-\pi$ stacking interactions (between ring N1-C1-C2-C3-C4-C5 and ring N7-N8-C26-C27-C28, centroid-to-centroid $3.6350 \AA$ ).

Structure of $\left\{\left[\mathbf{C d}(\text { pypya)(ta) })_{1 / 2}\right] \cdot \mathbf{H}_{2} \mathrm{O}\right\}_{\mathbf{n}}$ (1). Single-crystal $\mathrm{X}$-ray diffraction analysis reveals that complex $\mathbf{2}$ crystallizes in the triclinic system, with space group $P-1$. The asymmetric unit of complex 2 is composed of one $\mathrm{Cd}$ (II) ion, one

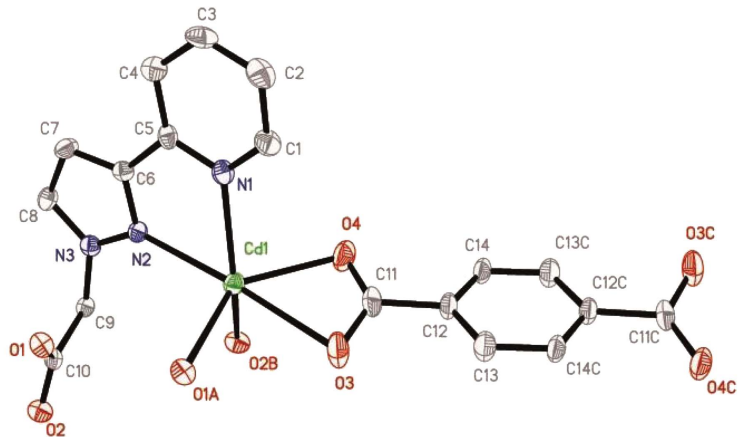

Figure 4. Coordination environment of $\mathrm{Cd}(\mathrm{II})$ atom in complex 2 with thermal ellipsoids at $30 \%$ probability level.

pypya anion, half of ta anion and one water molecule. The $\mathrm{Cd}(\mathrm{II})$ center is coordinated by two nitrogen atoms from pypya anion, two carboxylic oxygen atoms from two pypya anions and two carboxylic oxygen atoms from ta anion to form a six-coordinated distorted octahedral geometry (Figure 4). The Cd-N distances fall in the range 2.320-2.438 $\AA$, while the $\mathrm{Cd}-\mathrm{O}$ distances range from 2.230 to $2.569 \AA$. The $\mathrm{Cd}-\mathrm{N}$ and $\mathrm{Cd}-\mathrm{O}$ distances agree well with reported values. ${ }^{28}$ The water molecule of the asymmetric unit does not take part in coordination. It is linked to $\mathrm{O} 3$ via hydrogen bond, and the length of the hydrogen bond in $2.853 \AA$.

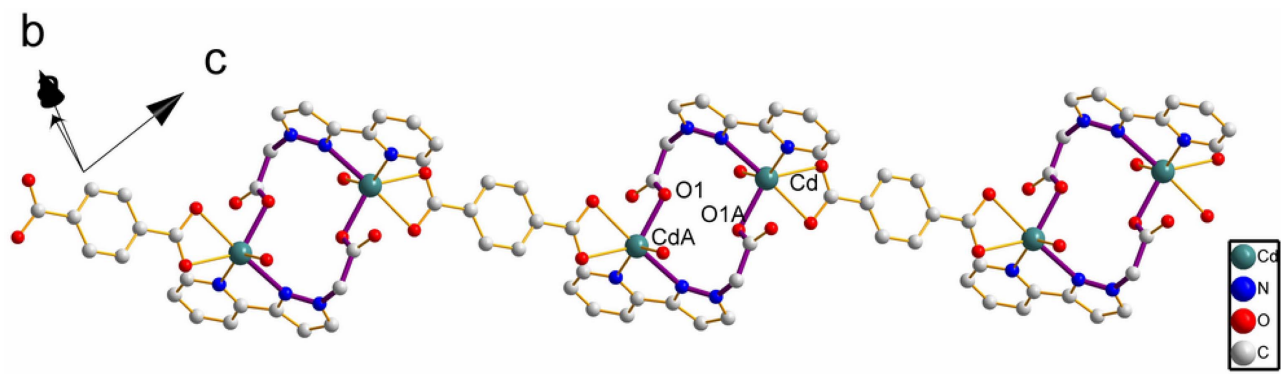

Figure 5. The 1D supramolecular architecture of complex 2.

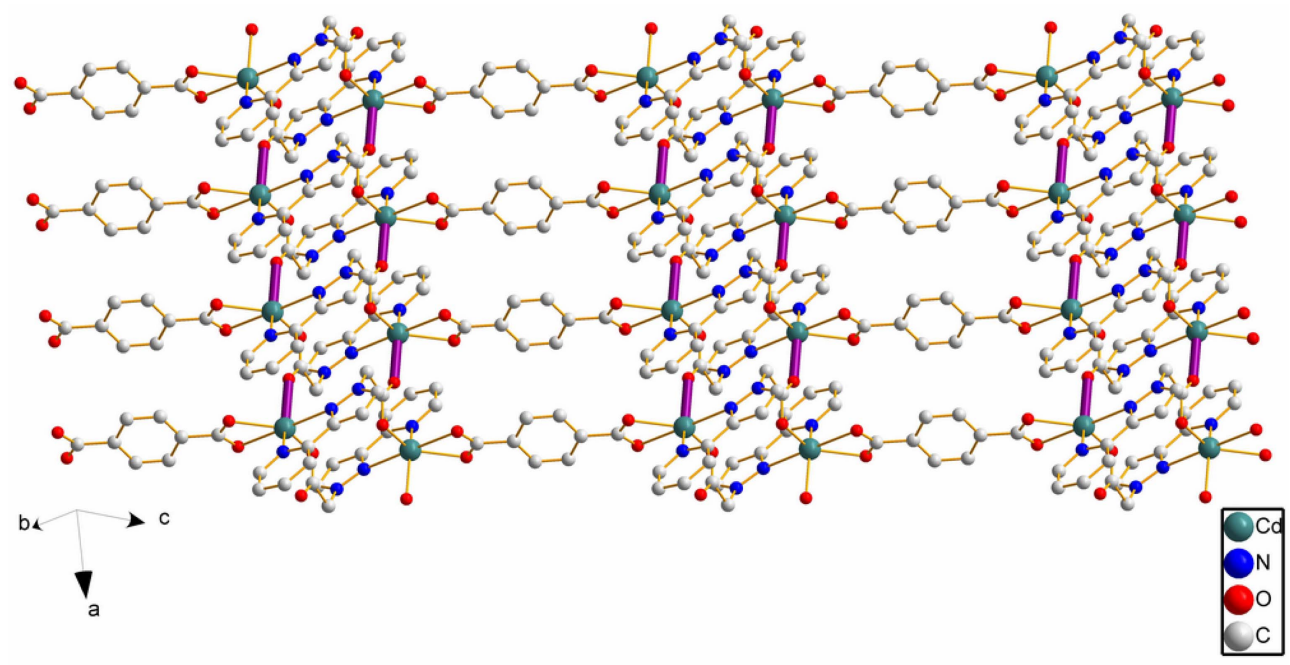

Figure 6. The 2D network structure of complex 2 . 


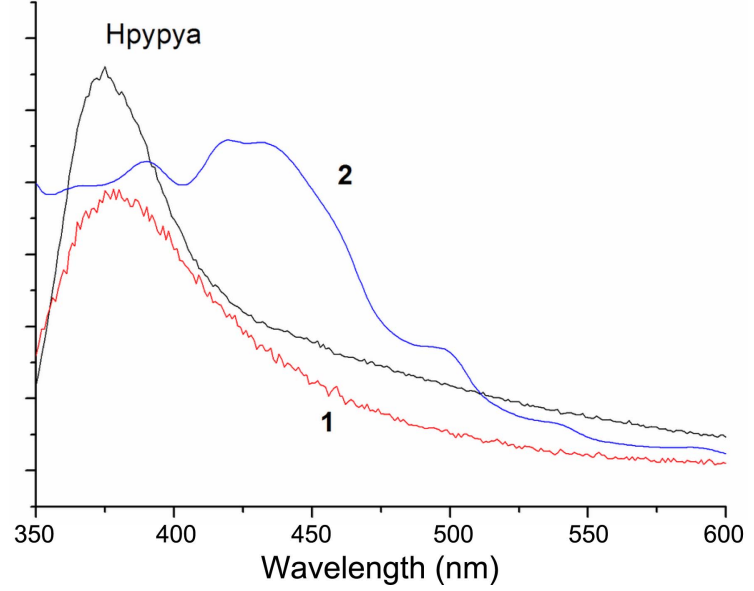

Figure 7. Solid emission spectra of complex 1, complex 2 and ligand Hpypya at room temperature.

As shown in Figure 5, adjacent pypya anions are bridged by $\mathrm{Cd}$ ions to form 12-membered rings. These $\mathrm{Cd}$ ions from above rings are further coordinated by carboxylic oxygen atoms from ta anions. As a result, those rings are linked by ta anions. Thus, infinite one-dimensional (1D) chains are formed. As shown in picture, adjacent chains are linked by $\mathrm{Cd}-\mathrm{O}$ bonds. Thus, a two-dimensional (2D) network structure is formed (Figure 6).

Thermal Stability. Thermogravimetric analysis (TGA) was carried out in the interest of studying the thermal stability of complex 1 and complex 2 . The TGA curve of complex 1 shows two main weight loss stages (Figure S1). The initial weight loss of $13.1 \%$ in the $50-160{ }^{\circ} \mathrm{C}$ temperature range is corresponding to water molecules $(14.1 \%$ calculated). When the temperature is above $350{ }^{\circ} \mathrm{C}$, the product begins to decompose and oxidize. The residual weight percentage at the end of the decomposition of complex $\mathbf{1}$ is consistent with the formation of $\mathrm{CuO}$, and the observed residue percentage is $18.7 \%$ ( $17.8 \%$ calculated).

The thermal decomposition process of complex 2 can be divided into two stages (Figure S2). The initial stage starts from $100^{\circ} \mathrm{C}$ to $150{ }^{\circ} \mathrm{C}$ with the weight loss of $4.9 \%$, which corresponds to the loss of water molecules ( $4.3 \%$ calculated). The second weight loss occurs in the range of 320 to $460{ }^{\circ} \mathrm{C}$, where the product begins to decompose and oxidize. The residual weight percentage at the end of the decomposition of complex $\mathbf{2}$ is consistent with the formation of $\mathrm{CdO}$, and the observed residue percentage is $27.8 \%$ ( $30.8 \%$ calculated).

Fluorescence Spectra. The fluorescence spectra of complex 1, complex 2 and ligand Hpypya in the solid state was measured at room temperature, with the results shown in Figure 7. The excitation wavelengths of complex 1, complex 2 and ligand are at 320, 335 and $283 \mathrm{~nm}$, respectively. The emission peaks of complex 1 and ligand Hpypya are all at $375 \mathrm{~nm}$. Considering the structures of the ligand Hpypya and complex 1, the emissions probably originated from the ligand-centered $\pi-\pi^{*}$ transition. Coordination does not change the position of emission peak, the fluorescent quenching of $\mathrm{Cu}$ (II) only influences the emission strength of complex $\mathbf{1}$.
Table 5. Mulliken atomic charges (e) for $\mathbf{1}$ and ligand pypya

\begin{tabular}{ccc}
\hline Atom & $\mathbf{1}$ & pypya \\
\hline Cu1 & 0.682 & \\
Cu2 & 0.711 & \\
N1 & -0.652 & -0.104 \\
N4 & -0.582 & -0.104 \\
N18 & -0.644 & -0.104 \\
N2 & -0.277 & -0.457 \\
N5 & -0.368 & -0.457 \\
N7 & -0.303 & -0.457 \\
O2 & -0.599 & -0.608 \\
O3 & -0.605 & -0.608 \\
\hline
\end{tabular}

It's known from literature ${ }^{29}$ that ligand ta is non-fluorescent. Complex 2 has two emission peaks at 385 and $430 \mathrm{~nm}$, respectively, probably due to two kinds of ligands pypya and ta, owning different emission peak. Coordination with $\mathrm{Cd}$ ions red-shifted the emission peaks of pypya and ta ligands. The result suggests that complex $\mathbf{2}$ is potential luminescent material.

Computation Results. To get an insight on the electronic structures and bonding properties of the complex $\mathbf{1}$, calculations via DFT methods were carried out. The optimized bond lengths and angles are presented in Table 2. In general, the calculated bond lengths and angles are in agreement with experimental crystal data and the largest differences $(\sim 0.0038$ $\left.\mathrm{nm}, \sim 1.6^{\circ}\right)$ may be noticed for deviations around $\mathrm{Cu} 1$ and $\mathrm{O} 7$ atoms.

Mulliken charge of the center metal $\mathrm{Cu}$ changed from +2 to 0.682 and 0.711 (Table 5), it is obvious $\mathrm{Cu}$ has been coordinated by the ligand and its charge transfered to the ligand. Compared to the free pypya ligand, the Mulliken charges of N1, N4 and N18 are reduced while N2, N5 and N7 increased. All these show strong complexation between $\mathrm{Cu}$ and its coordinated atoms. It is worth to note that the net atomic charges of N1, N4 and N18 (which are chemically identical in ligand pypya) are different. So are N2, N5 and N7. These differences confirm that, in the asymmetric unit of complex $\mathbf{1}$, the coordination modes of three pypya groups are not identical.

Based on the natural charges and electron configurations on the atoms of complex 1 and free pypya ligand which have been calculated by natural bond orbital (NBO) analysis (Table 6), one will find that, in complex $\mathbf{1}$, the electrons distribution in the outer orbital of coordinated nitrogen atoms have been increased, the natural charges of coordinated nitrogen atoms have been decreased, compared to ligand pypya. It can be considered that coordination bond effects increase the electron density of those coordinated nitrogen atoms. $\mathrm{As} \mathrm{Cu}(\mathrm{II})$ ions are electron-withdrawing, more electrons of ligand pypya are concentrated to coordinated nitrogen atoms.

An interesting feature, the schematic representation of HOMO and LUMO orbitals of the free pypya ligands in Figure 8, demonstrate higher MO distributions around oxy- 
Table 6. Natural configurations and natural charges for the atoms of complex 1 and pypya which calculated by B3LYP method

\begin{tabular}{|c|c|c|c|c|}
\hline \multirow{2}{*}{ Atom } & \multicolumn{2}{|l|}{ Complex 1} & \multicolumn{2}{|l|}{ Ligand Hpypya } \\
\hline & Configuration & Natural charge & Configuration & Natural charge \\
\hline $\mathrm{Cu} 1$ & [core]4S(0.33)3d(9.34)4p(0.31)5p(0.01) & 1.017 & & \\
\hline $\mathrm{Cu} 2$ & {$[$ core] $4 \mathrm{~S}(0.30) 3 \mathrm{~d}(9.31) 4 \mathrm{p}(0.42) 5 \mathrm{p}(0.01)$} & 0.971 & & \\
\hline $\mathrm{N} 1$ & {$[$ core $] 2 S(1.32) 2 p(4.18) 3 p(0.01)$} & -0.513 & {$[$ core] $2 \mathrm{~S}(1.36) 2 \mathrm{p}(4.05) 3 \mathrm{p}(0.02)$} & -0.434 \\
\hline N4 & {$[$ core $] 2 S(1.33) 2 p(4.15) 3 p(0.01)$} & -0.487 & {$[$ core] $2 S(1.36) 2 p(4.06) 3 p(0.01)$} & -0.434 \\
\hline N18 & {$[$ core] $2 S(1.32) 2 p(4.17) 3 p(0.01)$} & -0.499 & {$[$ core] $2 S(1.36) 2 p(4.06) 3 p(0.01)$} & -0.434 \\
\hline $\mathrm{N} 2$ & {$[$ core] $2 S(1.35) 2 p(3.98) 3 p(0.01)$} & -0.340 & {$[$ core] $2 S(1.42) 2 p(3.82) 3 p(0.02)$} & -0.266 \\
\hline N5 & {$[$ core] $2 \mathrm{~S}(1.34) 2 \mathrm{p}(3.96) 3 \mathrm{p}(0.02)$} & -0.324 & {$[$ core] $2 \mathrm{~S}(1.42) 2 \mathrm{p}(3.82) 3 \mathrm{p}(0.02)$} & -0.266 \\
\hline N7 & {$[$ core] $2 \mathrm{~S}(1.37) 2 \mathrm{p}(3.92) 3 \mathrm{p}(0.01)$} & -0.307 & [core] $2 \mathrm{~S}(1.42) 2 \mathrm{p}(3.82) 3 \mathrm{p}(0.02)$ & -0.266 \\
\hline $\mathrm{O} 2$ & [core] $2 \mathrm{~S}(1.69) 2 \mathrm{p}(5.00) 3 \mathrm{p}(0.01)$ & -0.701 & [core] $2 \mathrm{~S}(1.73) 2 \mathrm{p}(5.034) 3 \mathrm{p}(0.01)$ & -0.711 \\
\hline $\mathrm{O} 3$ & {$[$ core] $2 \mathrm{~S}(1.72) 2 \mathrm{p}(5.01) 3 \mathrm{p}(0.01)$} & -0.753 & {$[$ core] $2 S(1.73) 2 p(5.02) 3 p(0.02)$} & -0.711 \\
\hline
\end{tabular}

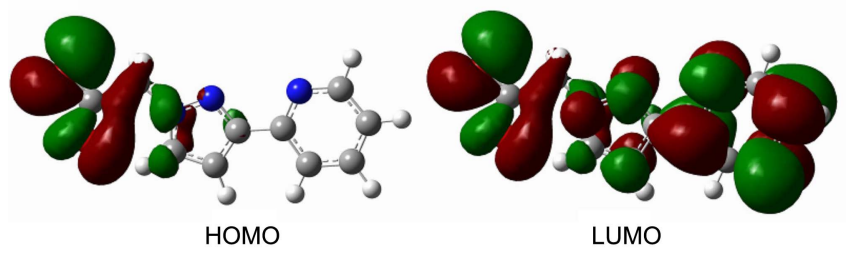

Figure 8. The 3D representation of HOMO and LUMO frontal orbitals of free (pypya) $)^{-}$ligand.

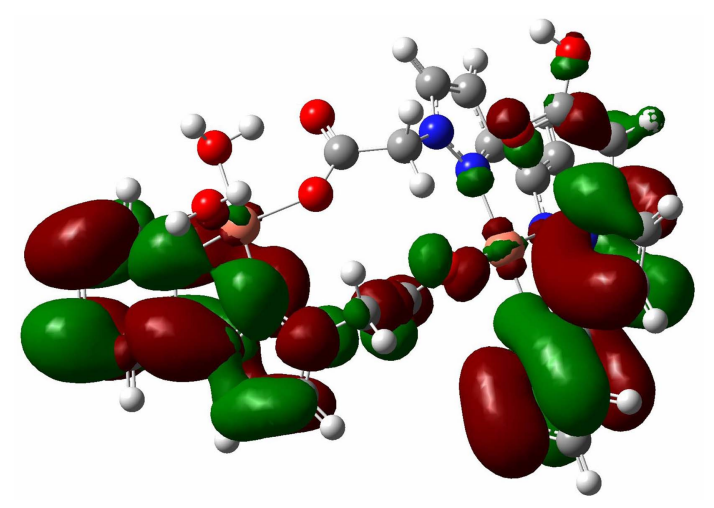

Figure 9. HOMO orbitals of complex 1.

gen atoms in HOMO and nitrogen atoms in LUMO frontal orbitals. As would be expected and the HOMO orbitals of complex 1 show in Figure 9, the overlapping of the electron clouds have been done between ligands with atomic orbitals of $\mathrm{Cu}$ metal.

\section{Conclusion}

In this work, we synthesized two novel supramolecular compounds $\left[\mathrm{Cu}_{2}(\text { pypya })_{3}\left(\mathrm{H}_{2} \mathrm{O}\right)_{2}\right] \cdot \mathrm{Cl} \cdot\left(\mathrm{H}_{2} \mathrm{O}\right)_{5}(\mathbf{1})$ and $\{[\mathrm{Cd}($ pypya $)-$ (ta) $\left.\left.)_{1 / 2}\right] \cdot \mathrm{H}_{2} \mathrm{O}\right\}_{\mathrm{n}}(2)$ by solvent evaporation method and hydrothermal method respectively. In complex 1, $\mathrm{Cu}$ (II) ions adopt five-coordinated geometry $\left(\mathrm{CuN}_{2} \mathrm{O}_{3}\right.$ or $\left.\mathrm{CuN}_{2} \mathrm{O}_{3}\right)$, while hydrogen bonds and $\pi-\pi$ interactions play crucial roles in the construction of the three-dimensional (3D) network architecture. Different from complex 1, complex $\mathbf{2}$ is a coordination polymer. In complex $\mathbf{2}, \mathrm{Cd}(\mathrm{II})$ ions, pypya anions and ta anions are bonded together via coordination bonds, and two-dimensional (2D) structure are formed. The DFT calculations of the complex 1 and Ligand pypya at the B3LYP level of theory verifies that the special coordination behavior have been occurred in the complex 1. Our results provide an effective route for the preparation of supramolecular architectures.

Supplementary Material. Crystallographic data for the structure reported here have been deposited with the Cambridge Crystallographic Data Centre. CCDC 963155 and 978923 contain the supplementary crystallographic data for complex 1 and complex 2, respectively. The data can be obtained free of charge via http:/www.ccdc.cam.ac.uk/cperl/ catreq.cgi (or from the CCDC, 12 Union Road, Cambridge CB2 1EZ, UK; Tel: (+44) 1223-336-408; Fax: (+44) 1223336-033; E-mail: deposit@ccdc.cam.ac.uk)

Acknowledgments. Publication cost of this paper was supported by the Korean Chemical Society.

\section{References}

1. James, S. L. Chem. Soc. Rev. 2003, 32, 276.

2. Zhao, B.; Cheng, P.; Chen, X.; Cheng, C.; Shi, W.; Liao, D. Angew. Chem. Int. Ed. 2003, 42, 934.

3. Wang, R.; Hong, M.; Luo, J.; Cao, R.; Weng, J. Chem. Commun. 2003, 1018.

4. Zhu, K.; Xu, H. M.; Liu, G. X. Chinese J. Inorg. Chem. 2009, 25 , 1677.

5. Cerdeira, A. C.; Simão, D.; Santos, I. C.; Machado, A.; Pereira, L. C. J.; Waerenborgh, J. C.; Almeida, M. Inorg. Chim. Acta 2008, $361,3836$.

6. Estrader, M.; Diaz, C.; Ribas, J.; Solans, X. Inorg. Chim. Acta 2008, 361, 3963.

7. Zhai, Q. G.; Li, S. N.; Gao, X.; Ji, W. J.; Jiang, Y. C.; Hu, M. C. Inorg. Chem. Commun. 2010, 13, 211.

8. Henninger, S. K.; Habib, H. A.; Janiak, C. J. Am. Chem. Soc. 2009, 131, 2776.

9. Habib, H. A.; Hoffmann, A.; Höppe, H. A.; Steinfeld, G.; Janiak, C. Dalton Trans. 2009, 10, 1742.

10. Li, D. S.; Fu, F.; Zhao, J.; Wu, Y. P.; Du, M.; Zou, K.; Wang, Y. Y. Dalton Trans. 2010, 39, 11522 .

11. Zeng, M. H.; Wang, Q. X.; Tan, Y. X.; Hu, S.; Zhao, H. X.; Long, 
L. S.; Kurmoo, M. J. Am. Chem. Soc. 2010, 132, 2561.

12. Yang, J.; Shen, L.; Yang, G. W.; Li, Q. Y.; Zhu, L. L.; Shen, W. Inorg. Chim. Acta 2012, 392, 25.

13. Li, Q. Y.; He, M. H.; Shen, Z. D.; Yang, G. W.; Yuan, Z. L. Inorg. Chem. Commun. 2012, 20, 214.

14. Figueiredo, S.; Gomes, A. C.; Neves, P.; Amarante, T. R.; Almeida Paz, F. A.; Soares, R. Inorg. Chem. 2012, 51, 8629.

15. Mareque Rivas, J. C.; Brammer, L. Coord. Chem. Rev. 1999, 183, 43.

16. Lee, C. K.; Chen, J. C.; Lee, K. M.; Liu, C. W.; Lin, I. J. Chem. Mater. 1999, 11, 1237.

17. Zeng, X. Y.; He, Y. H.; Feng, Y. L. Chinese J. Inorg. Chem. 2008, $24,1400$.

18. Liu, S. W.; Wu, X. M.; Liu, Q. X. Chinese J. Inorg. Chem. 2008, $24,1444$.

19. Bruker. SADABS, SAINT, and SMART. Bruker AXS Inc., Madison, Wisconsin, USA, 2002.
20. Sheldrick, G. M. Acta Cryst. 2008, A64, 112.

21. Frisch, M. J. et al. Gaussian 03, revision C.02. wallinordford, CT: Gaussian, Inc.; 2004.

22. Becke, A. D. J. Chem. Phys. 1993, 98, 5648.

23. Lee, C.; Yang, W.; Parr, R. G. Phys. Rev. 1988, 37, 785.

24. Vrkic, A. K.; Taverner, T.; James, P. F.; Richard, A. J. Dalton Trans. 2004, 2, 197.

25. Chawla, S. K.; Arora, M.; Nättinen, K.; Rissanen, K.; Yakhmi, J. V. Polyhedron 2004, 23, 3007.

26. Qiu, G. M.; Wang, C. J.; Zhang, Y. J.; Huang, S.; Liu, X. L.; Zhang, B. J.; Zhou, X. L. Bull. Korean Chem. Soc. 2012, 33, 2603.

27. Yang, J.; Ma, J. F.; Liu, Y. Y.; Ma, J. C.; Batten, S. R. Cryst. Growth Des. 2008, 8, 4383.

28. Liu, G. X.; Xu, Y. Y.; Ren, X. M. Chinese J. Inorg. Chem. 2010 , 10, 029.

29. Barreto, J. C.; Smith, G. S.; Strobel, N. H.; McQuillin, P. A.; Miller, T. A. Life Sciences 1994, 56, 89. 